Issued by Sandia National Laboratories, operated for the United States Department of Energy by Sandia Corporation.

NOTICE: This report was prepared as an account of work sponsored by an agency of the United States Government. Neither the United States Government nor any agency thereof, nor any of their employees, nor any of their contractors, subcontractors, or their employees, makes any warranty, express or implied, or assumes any legal liability or responsibility for the accuracy, completeness, or usefulness of any information, apparatus, product, or process disclosed, or represents that its use would not infringe privately owned rights. Reference herein to any specific commercial product, process, or service by trade name, trademark, manufacturer, or otherwise, does not necessarily constitute or imply its endorsement, recommendation, or favoring by the United States Government, any agency thereof, or any of their contractors or subcontractors. The views and opinions expressed herein do not necessarily state or reflect those of the United States Government, any agency thereof, or any of their contractors.

Printed in the United States of America. This report has been reproduced directly from the best available copy.

Available to DOE and DOE contractors from Office of Scientific and Technical Information PO Box 62

Oak Ridge, TN 37831

Prices available from (615) 576-8401, FTS 626-8401

Available to the public from

National Technical Information Service

US Department of Commerce

5285 Port Royal Rd.

Springfield, VA 22161

NTIS price codes

Printed Copy: A03

Microfiche Copy: A01 
SAND 98-0505/2

UC-900

March 1998

\title{
Siachen Science Center: A Concept for Cooperation at the Top of the World
}

\author{
Kent L. Biringer \\ Principal Member of the Technical Staff, \\ Cooperative Monitoring Center, \\ Sandia National Laboratories
}

Cooperative Monitoring Center Occasional Paper/2

\section{(1) Sandia National Laboratories}

Sandia is a multiprogram laboratory operated by Sandia Corporation, a Lockheed Martin Company, for the United States Department of Energy under contract DE-AC04-94AL85000.

DISTRIBUTION OF THIS DOCUMENT IS UNLIMTED

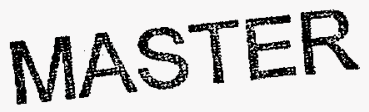


The Cooperative Monitoring Center (CMC) at Sandia National Laboratories assists political and technical experts from around the world to acquire the technology-based tools they need to assess, design, analyze and implement nonproliferation, arms control and other cooperative security measures. As part of its mission, the CMC sponsors research on cooperative security and the role of technology. Reports of that work are provided through the Occasional Papers series. Research is conducted by Sandia staff as well as visiting scholars. The CMC visiting scholars program is administered by the Institute for Public Policy at the University of New Mexico. For additional information on the programs of the $\mathrm{CMC}$, visit the $\mathrm{CMC}$ home page on the World Wide Web at <http://www.cmc.sandia.gov> or write to:

Cooperative Monitoring Center

Sandia National Laboratories

Mail Stop 1373

Albuquerque, NM 87185-1373

For specific information on this report contact:

Kent L. Biringer at the above address.

This report was prepared by Sandia National Laboratories Albuquerque, NM 87185 and Livermore, CA 94550 


\section{DISCLAIMER}

Portions of this document may be illegible electronic image products. Images are produced from the best available original document. 


\title{
Siachen Science Center: A Concept for Cooperation at the Top of the World
}

\begin{abstract}
India and Pakistan have engaged in a long-running military dispute in the Siachen Glacier region of northern Kashmir since 1984. In recent years, several unsuccessful attempts have been made to end the conflict. Despite continuing hostilities, there remains a strong interest in resolving the dispute and eliminating the human and financial costs associated with maintaining troops on the highest battlefield in the world. One resolution to the problem could be the establishment of a scientific research center in the region.

The military forces in the region would be replaced with scientists and engineers from both countries who would advance knowledge in science and engineering by operating a high-altitude research station for the study of basic sciences, engineering, and human physiology. The high altitude, remote location, and unique geology would provide an unprecedented opportunity for ground-breaking research. The paper discusses options for such research and precedents, such as the Antarctic Treaty, for research in other hostile environments.
\end{abstract}


This page intentionally left blank. 


\section{Contents}

1. BACKGROUND

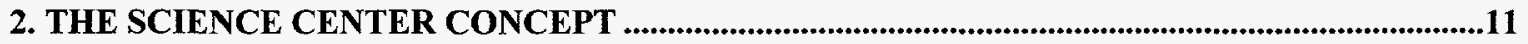

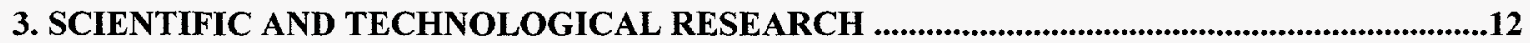

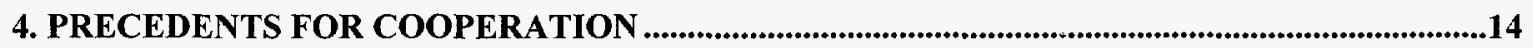

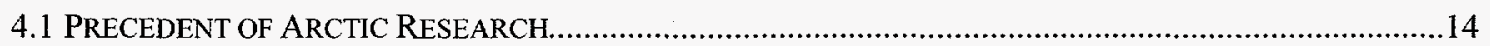

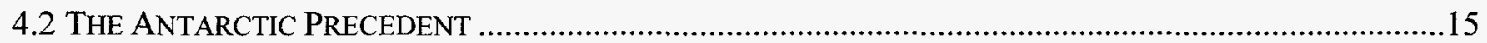

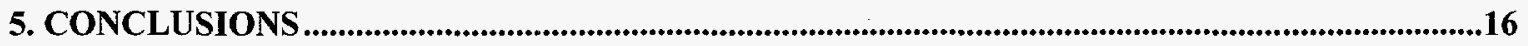

APPENDIX-THE ANTARCTIC TREATY AND ITS APPLICATION TO SIACHEN .......................17

\section{Figures}

Figure 1. Composite Satellite Image of Siachen Glacier Region ....................................9

Figure 2. Military Troops are Deployed at Extreme Elevations ...................................10

Figure 3. Example Field Research Station in Antarctica ...........................................11

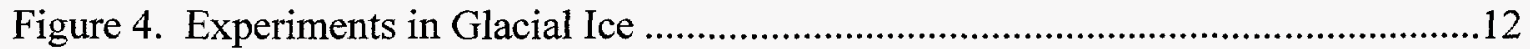

Figure 5. Deploying a Remote Monitoring System ......................................................13

Figure 6. NOAA Weather Satellite Image of Antarctica using Advanced Very High

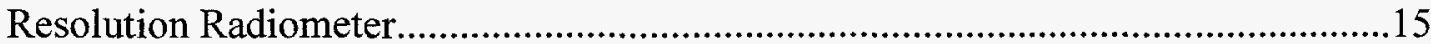

Figure 7. Antarctic Territorial Claims .................................................................... 19 


\section{Acronyms}

$\begin{array}{ll}\text { ATP } & \text { Advanced Telescope Project } \\ \text { CMC } & \text { Cooperative Monitoring Center } \\ \text { LOC } & \text { Line of Control } \\ \text { NOAA } & \text { National Oceanographic and Atmospheric Administration } \\ \text { SPIREX } & \text { South Pole Infrared Explorer }\end{array}$

ATP

Advanced Telescope Project

Cooperative Monitoring Center

Ocel

National Oceanographic and Atmospheric Administration

NOAA

South Pole Infrared Explorer 


\section{Siachen Science Center: A Concept for Cooperation at the Top of the World}

\section{Background}

As India and Pakistan each celebrate their 50th year of independence, there is optimism that a new era of cooperation may be emerging. During the 50 years since the partition of these countries, the region has been plagued by conflict. Three major wars have been fought between India and Pakistan over that period and one war was fought between China and India. After the first India/Pakistan war in 1948, the princely state of Kashmir was divided under terms of the Karachi agreement. India and Pakistan defined a ceasefire line for most, but not all, of the disputed region. Once the cease-fire line reached a particular point high in the Karakoram Mountains, referred to by its map coordinates as NJ 9842, the agreement specified an extension of the cease-fire line "thence north to the glaciers." One of the primary features in that region is the Siachen Glacier, the longest in the Himalayas. Pakistan interpreted the line to proceed northeastward to the Karakoram Pass on the Chinese border. The Indians interpreted it to go along the Saltoro Range and Siachen Glacier northwest to the Chinese border. (See Figure 1.)

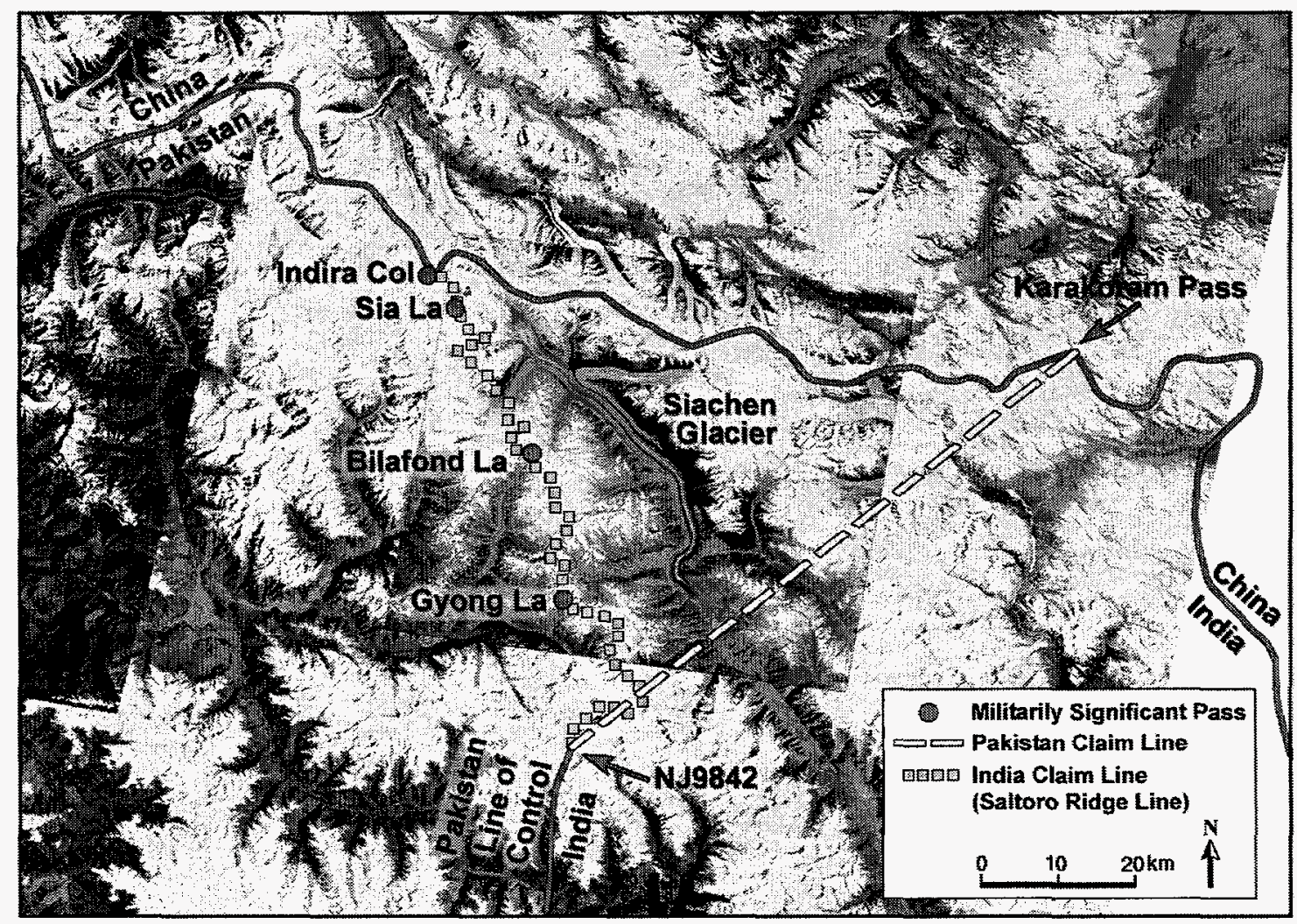

Figure 1. Composite Satellite Image of Siachen Glacier Region

(Image processing by Earth Data Analysis Center, University of New Mexico) 
With only slight adjustments in the cease-fire line after subsequent wars, the division of Kashmir has continued. However, in 1984, in response to perceived Pakistani claims, Indian troops suddenly occupied an area of the Siachen Glacier and questioned the interpretation of the phrase "thence north to the glaciers." The result was an area of about 1000 square miles of disputed territory high in the Himalayas. The Siachen Glacier region thus became a 20,000-foot elevation battleground between India and Pakistan. (See Figure 2.)

Although troops have been killed in the skirmishes that have occurred on this highest battlefield in the world, more are reported to have died and been injured by the inhospitable nature of the environment.

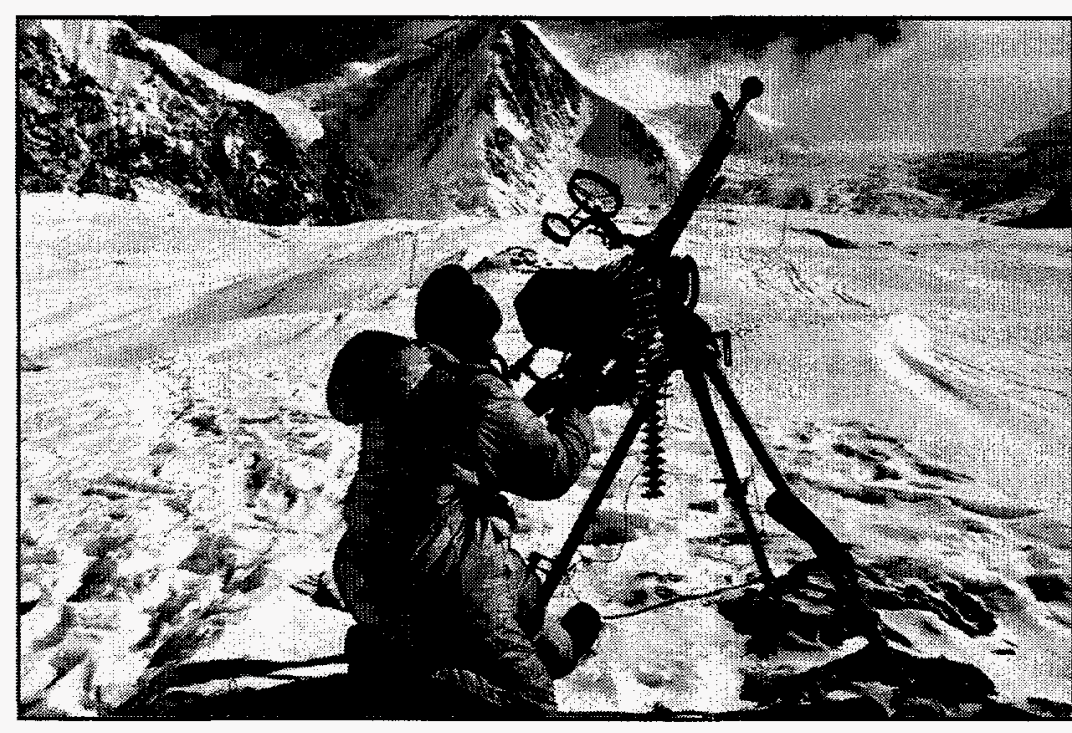

Figure 2. Military Troops are Deployed at Extreme Elevations ${ }^{1}$
While there are differing views on the military significance, the Siachen dispute has an undeniably strong political significance. However, as India and Pakistan have worked to reach agreement on many issues over the years, Siachen has been discussed as a potential location for cooperation by the two sides through disengagement of troops from the region. In 1989 and again in 1993, a settlement on the issue was nearly reached. The costs in financial and human terms of continuing this confrontation make it an excellent candidate for cooperation while minimizing strategic or military disadvantage.

Many factors will influence a resolution of the Siachen conflict. While political will is the predominant factor, it will be affected by other issues. The desire to reduce human suffering and to save money are two examples of important factors that justify resolution. Mechanisms will be required to support political will by providing assurance that terms of agreements are met. These mechanisms may include monitoring systems, inspection regimes, and cooperative projects, all of which can help ensure compliance with an agreement. While a variety of resolutions and many monitoring options are possible, this paper will develop a single confidence building measure that may contribute to resolution of the Siachen dispute.

\footnotetext{
'Photo used by permission. Martin A. Sugarman, War Above the Clouds: Siachen Glacier, Sugarman Productions, Malibu, California, 1996.
} 


\section{The Science Center Concept}

The concept introduced in this paper is to substitute a scientific presence in the Siachen region for the military one. The goal of establishing a "Siachen Science Center" would be to satisfy the requirement for a national presence in the area that would help ensure terms of a military disengagement agreement, while advancing the cause of science in many fields. The project could be conducted cooperatively between the Indians and Pakistanis but with the possibility of other regional and international participants and sponsors. The balance of this paper will describe the Science Center concept and precedents for similar cooperative efforts. (See Figure 3 for an example of a field research station in Antarctica.)

While the nature of an agreement on Siachen could take many forms, the Science Center concept assumes an agreement in which a designated area would be set aside for peaceful scientific use only. The signatories to such an agreement would seek peaceful coexistence. Other parties could become signatories in various support or participation categories. Establishing a center for scientific research in the Himalayas would provide a unique location for specialized research as well as the possibility to be integrated into other regional and international networks of scientific research stations. International participation could take the form of providing any combination of funding, research or operational manpower, guidance, or administration.

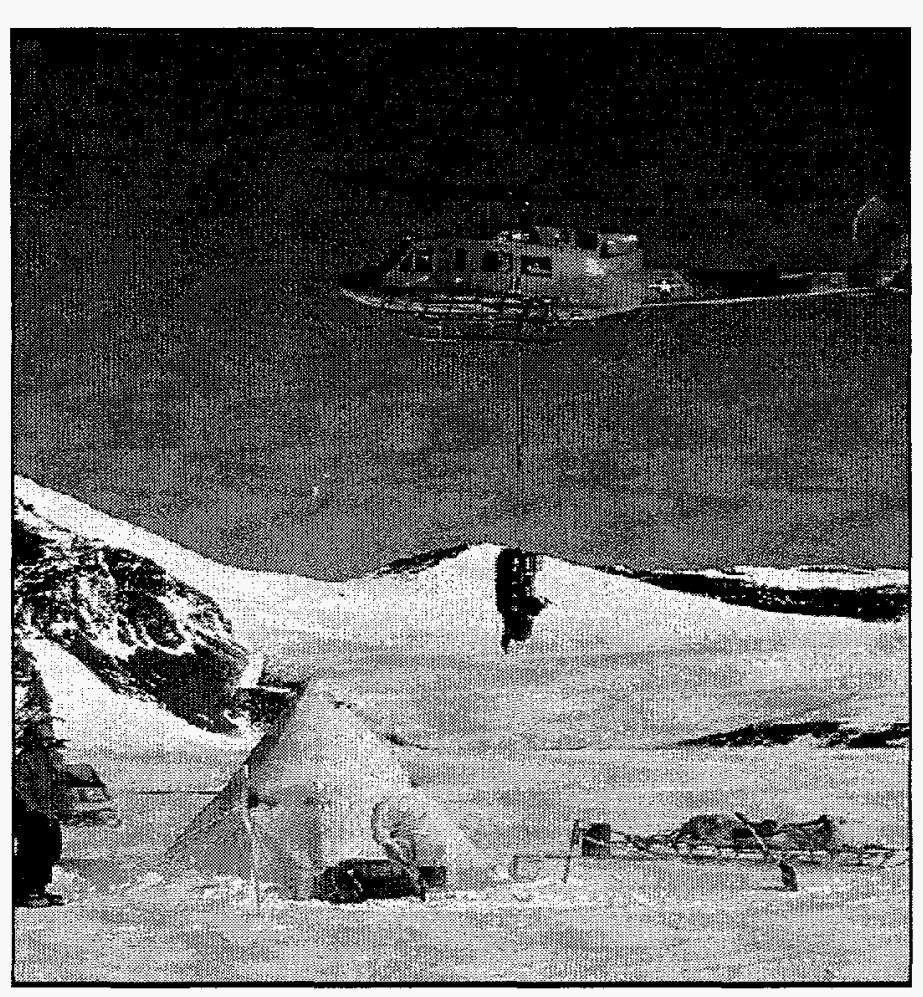

Figure 3. Example Field Research Station in Antarctica ${ }^{2}$
The Siachen Science Center would consist of a scientific research facility within a designated zone in the Karakoram Range. It would consist of a base camp with the potential for outlying field sites where scientific instruments could be placed. Smaller-scale outposts in the vicinity of the base station are also possible. The Center would be staffed by scientists, engineers, and technicians conducting research, along with necessary support personnel for cooking, facility maintenance, communications, and medical needs. The staff could be a mix of bilateral, regional or multinational personnel.

\footnotetext{
${ }^{2}$ Photo courtesy of Antarctic Support Associates
} 


\section{Scientific and Technological Research}

The location high in the Karakoram Range in the western part of the Himalayan Mountains offers many advantages as a base for conducting scientific research. Depending on specific siting of the facility it has the potential to be the highest altitude manned research station in the world. That fact, coupled with the isolated location, unique geology, and geographical position, make it a special location for research.

Several scientific missions are possible, as follows:

1) Astronomy - The high altitude of the Siachen Glacier would enhance astronomical research high above much of the earth's atmosphere. The remoteness of the location away from sources of light pollution is an advantage for astronomy.

2) Geology - The potential to increase the geological knowledge of this region is great. A more detailed understanding of rock origins as well as plate tectonic movements could be developed through systematic study of local rock outcroppings.

Paleontology studies of fossil records in the area could further define the geologic history of the area.

3) Atmospheric Sciences-Atmospheric science would benefit from a more comprehensive study of weather patterns in the complex terrain of the Himalayas. A series of meteorological stations could enable more accurate weather forecasting. A study of atmospheric and ice-bound pollution could also provide useful information on global as well as regional pollution concerns.

4) Glaciology — Glaciology studies can provide insight into climatic variations throughout history. (See Figure 4.) Snowfall and glacial melt provide the source of rivers such as the Indus. Therefore, hydrologic studies may provide insight into relationships between snowfall, glacial activity, and river flows in critical water resources.

5) Life Sciences-Biological and botanical studies of life in this high, harsh environment would also add to collective scientific knowledge.

6) Physiology-Physiological studies of the effects of high altitude on humans are possible in a controlled manner in this high-altitude laboratory. This could lead to improved methods for preventing high altitude sicknesses and treating those

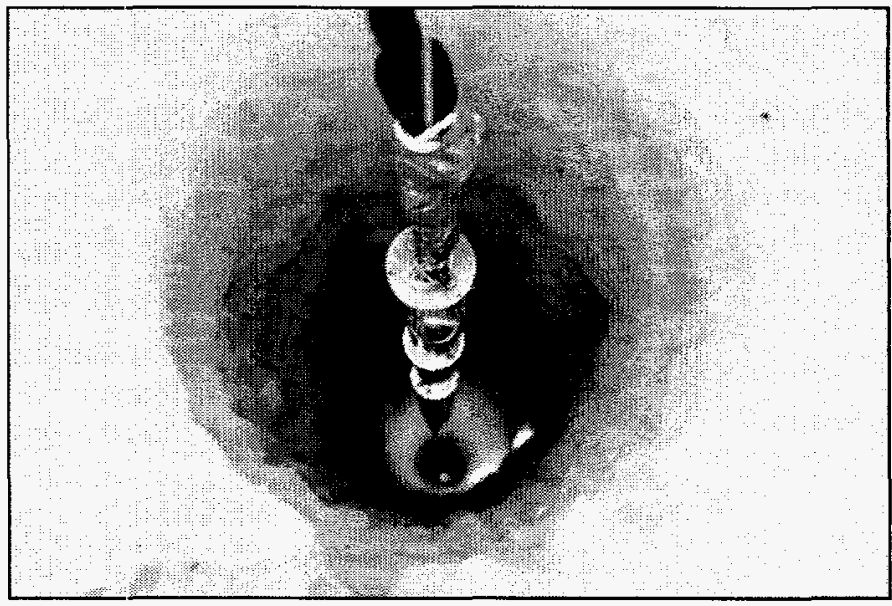

Figure 4. Experiments in Glacial Ice

(Photo courtesy of University of Chicago) who suffer from them. 
7) Psychology and Behavioral Sciences-Investigating the effects of a multinational group working together for prolonged periods in this hostile climatic environment.

In addition to the representative scientific topics listed above, engineering knowledge could be gained from deployment and operation of such a science center. Lessons will be learned in the design, deployment, and operation of the severe climate shelters needed for this glacier science station. Many of the communications and logistical issues associated with supplying and maintaining a remote installation provide a chance to add to knowledge and demonstrate cooperation on these subjects.

The Center can also serve as a test bed for characterization and operation of monitoring systems in a severe environment. These sensors could include cameras, ground and motion sensors, environmental and meteorological equipment, as well as remote power systems such as wind generators and solar photovoltaic arrays. (See Figure 6.) One can even envision a Siachen World Wide Web site that could include monitoring information from the glacier. The Australian Antarctic Division has such a capability on their Internet

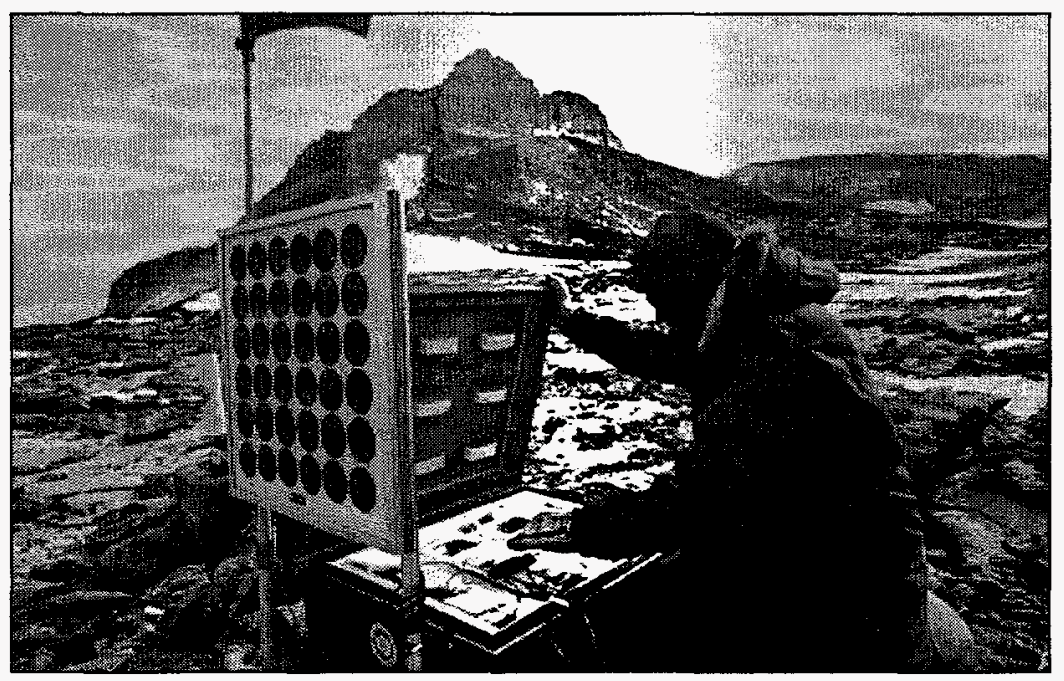

Figure 5. Deploying a Remote Monitoring System ${ }^{3}$ site in which a photograph and current weather conditions at their Mawson Station in the Antarctic can be viewed over the Internet. $^{4}$

There are nearly endless possibilities for research and monitoring opportunities in such a center. The topics listed above are only intended to be representative of those that may be of interest to South $A$ sian countries. Establishment of such a center could include a research board that could accept proposals for those wishing to pursue scientific or technical projects in that environment.

\footnotetext{
${ }^{3}$ Photo courtesy of Antarctic Support Associates

${ }^{4}$ Australian Antarctic Division, World Wide Web Home Page, http://www.antdiv.gov.au/
} 


\section{Precedents for Cooperation}

While the concept of cooperative scientific research may be a new one for application in South Asia, there are many precedents for different features of this proposal.

There is an extensive history of people working together in confined spaces in hostile environments. These include remote outposts such as lighthouses, radar sites, and military outposts (including Siachen itself). Commercial enterprises, such as mineral and oil exploration, often include establishment of remote outposts to develop and operate mines or oil fields. Examples include offshore oil production in locations such as the North Sea or Gulf of Mexico. Cold weather oil production stations, such as the one in Prudhoe Bay, Alaska, present another precedent from which to draw experience in designing, building, and operating the needed equipment and facilities. Other candidate programs from which to gain knowledge useful in establishing a Siachen Science Center include naval submarine programs and the U.S. and Russian space station and space shuttle programs. However, the most applicable precedents for establishing a South Asian center in the Siachen area come from scientific stations and outposts in the Arctic and Antarctic.

\subsection{Precedent of Arctic Research}

International efforts for cooperative arctic research include examples of land-based stations, ship-based research, ice-based monitors, and remotely transmitting buoy networks. The land-based stations reside in particular countries but have scholars and advisory boards that represent international participation. One example is the Arctic Centre in Finland which has an advisory board of 13 members representing 9 countries. A decision to deploy national research stations at Siachen could be addressed in a similar fashion.

Another cooperative example is that of the International Arctic Buoy Program that maintains a network of automatic data buoys in the Arctic Basin to monitor pressure, temperature, and ice motion. The program is funded and managed by eight countries. Over 24 international research institutes participate in the data collection and assessment. The Siachen area could similarly provide an opportunity to engage a variety of international participants in a similar cooperative research program.

Currently, the U. S. Department of Energy Atmospheric Radiation Measurement Program operates solar radiation and cloud measuring instruments on-board an icebreaker in the Arctic and at a station on the north slope of Alaska. ${ }^{5}$ The ship and instruments will drift amidst the arctic ice for a 13-month period. This effort is part of a U.S. Global Climate Change Research Program. These examples of scientific research in areas of isolation and hostile environments can provide useful lessons to those designing a regime for cooperative scientific research in the Siachen region.

\footnotetext{
5 "Arctic Cloud Station: Ambitious Program Puts Atmospheric Radiation Measurement Study on Ice," Sandia Lab News, Sandia National Laboratories, March 14, 1997.
} 


\subsection{The Antarctic Precedent}

Particularly pertinent to the Siachen issue is the precedent of the Antarctic Treaty of 1959. The treaty set aside the entire continent for peaceful scientific use only. (See Figure 6.) The 14 treaty articles outlined the requirements for successful coexistence on the continent. Since entry into force in 1961, 39 countries have become signatories to the treaty including the 7 states that originally laid claim to portions of the continent. Under terms of the treaty, all claims are held in abeyance for the term of the treaty and no new territorial claims can be submitted. India is one of the state parties to the treaty having acceded to the treaty on August 19, 1983. The Indian Department of Ocean Development coordinates and executes the national Antarctic program and maintains stations including one at Maitri Antarctica $\left(70^{\circ} 45^{\prime} \mathrm{S}, 11^{\circ} 44^{\prime} \mathrm{E}\right)$ which is operated throughout the year. The Pakistanis, although not signatories to the Antarctic treaty, maintain the Jinnah Station in Antarctica through their National Institute of Oceanography.

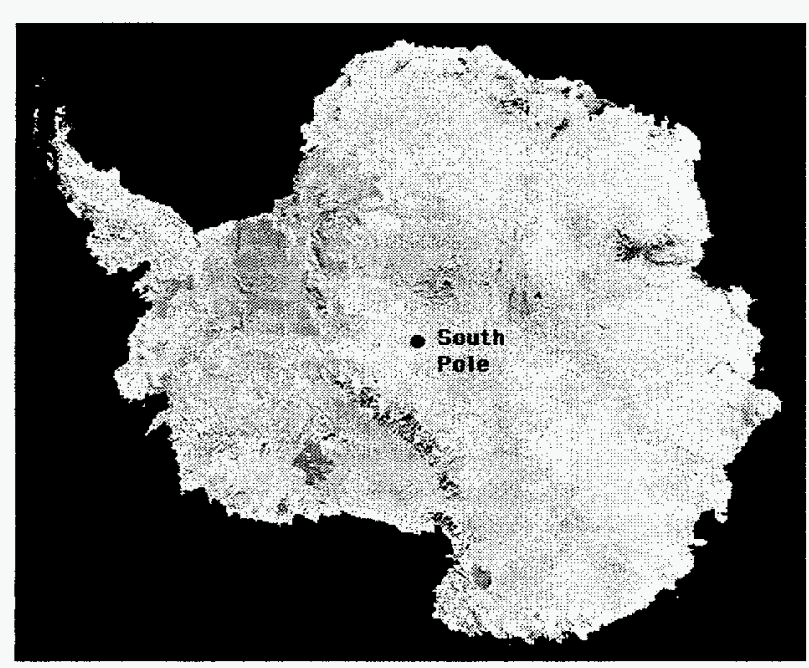

Figure 6. NOAA Weather Satellite Image of Antarctica using Advanced Very High Resolution Radiometer

(Photo courtesy of the University of Chicago)
The Antarctic Treaty bans any military activity in the defined area and prohibits nuclear testing. It limits national programs to those of scientific research and ensures the free exchange of information and scientists between countries. Inspection rights are granted to the facilities and operations of other countries with a presence on the continent. Provisions are made to have an open skies regime, enabling aerial observation at any time over any and all areas of Antarctica by any of the Contracting Parties that have the right to designate observers. Regular consultative meetings of the signatory states are held and disputes are resolved by peaceful negotiation including use of the International Court of Justice.

Currently 25 nations maintain a full-time presence on the continent. As of 1997, the treaty has been in force for 36 years. This represents one of the great accomplishments of international cooperation.

Research in the Antarctic is pursued in many of the scientific disciplines suggested for the Siachen Science Center. In the case of astronomy, for example, the Advanced Telescope Project (ATP) and South Pole Infrared Explorer (SPIREX) project collect information on the astronomical qualities of the region and study faint stars and galaxies.

While not a perfect model for South Asia, there are many features of the Antarctic Treaty that might be considered for application in Siachen. Some of these include 
demilitarization of the area of concern, dedication of the area to scientific research, establishment of research center(s) that share information and are open to joint inspection, deferring resolution of territorial claims, and resolving disputes through peaceful means. A detailed discussion of specific provisions of the Antarctic Treaty and their application to Siachen are included in the appendix.

\section{Conclusions}

Resolution of the Siachen Glacier dispute will require both political will and the monitoring and confidence building measures necessary to ensure compliance with agreements reached. The ideas presented in this paper offer one option that could contribute to confidence by providing for continued national presence on the Siachen Glacier while permitting military disengagement. The Siachen Science Center concept could serve the political needs of India and Pakistan while reducing costs, saving lives and contributing to the advancement of knowledge.

Several precedents demonstrate the feasibility of this concept for international scientific collaboration. Specific provisions of the Antarctic Treaty precedent, such as exclusive scientific use of an area, addressing issues of territorial claims, and restricting military activity, may have applicability in the South Asian context. For nearly 40 years the Treaty has been an outstanding example of international cooperation.

The political will to address issues of conflict in South Asia is growing as India and Pakistan begin the second half of their first century of independence. Governments in India and Pakistan appear interested in establishing increased dialogue and cooperation. The conflict on Siachen Glacier now appears to be a good candidate for such cooperation. The Siachen Science Center may offer one piece of the solution. 


\section{Appendix - The Antarctic Treaty and Its Application to Siachen}

This appendix provides the text of the 14 articles that make up the Antarctic Treaty. ${ }^{6}$ The text of each treaty article is followed by a brief description on the possible applicability of the treaty provisions to the Siachen dispute in South Asia.

\section{Article I}

1. Antarctica shall be used for peaceful purposes only. There shall be prohibited, inter alia, any measures of a military nature, such as the establishment of military bases and fortifications, the carrying out of military maneuvers, as well as the testing of any types of weapons.

2. The present treaty shall not prevent the use of military personnel or equipment for scientific research or for any other peaceful purpose.

These provisions would be consistent with the desired military withdrawal and demilitarization of the Siachen region. However, they would also permit the use of personnel and equipment from earlier military activities to be available to support establishment and operation of a peaceful and cooperative scientific center in the area.

\section{Article II}

Freedom of scientific investigation in Antarctica and cooperation toward that end, as applied during the International Geophysical Year, shall continue, subject to the provisions of the present Treaty.

This is the theme of the Siachen Science Center concept: that scientific investigation be the basis for cooperation in the area. The Antarctic Treaty built upon a year of joint scientific research by 12 nations in 1957-1958 (International Geophysical Year) in which studies of the Earth and it cosmic environment were conducted.

\section{Article III}

1. In order to promote international cooperation in scientific investigation in Antarctica, as provided for in Article II of the present Treaty, the Contracting Parties agree that, to the greatest extent feasible and practicable

(a) information regarding plans for scientific programs in Antarctica shall be exchanged to permit maximum economy and efficiency of operations;

(b) scientific personnel shall be exchanged in Antarctica between expeditions and stations;

\footnotetext{
${ }^{6}$ Arms Control and Disarmament Agreements: Texts and Histories of the Negotiations, United States Arms Control and Disarmament Agency, Washington, D. C., 1990.
} 
(c) scientific observations and results from Antarctica shall be exchanged and made freely available.

2. In implementing this Article, every encouragement shall be given to the establishment of co-operative working relations with those Specialized Agencies of the United Nations and other international organizations having a scientific or technical interest in Antarctica.

Sharing information is the key element of the cooperative monitoring concept. The Antarctic treaty envisioned different national research stations that would share information and collaborate. The Siachen Science Center concept could involve either separate national stations or a single jointly administered India/Pakistan station. The option for an even more diverse multinational station is also possible. Political decisions will determine which flags fly at such a center. It is likely that the center would establish relationships with $\mathrm{UN}$ and other international scientific and monitoring organizations as provided for in this Treaty Article.

\section{Article IV}

1. Nothing contained in the present Treaty shall be interpreted as:

(a) a renunciation by any Contracting Party of previously asserted rights of or claims to territorial sovereignty in Antarctica;

(b) a renunciation or diminution by any Contracting Party of any basis of claim to territorial sovereignty in Antarctica which it may have whether as a result of its activities or those of its nationals in Antarctica, or otherwise;

(c) recognition or non-recognition of any other State's right of or claim or basis of claim to territorial sovereignty in Antarctica.

2. No acts or activities taking place while the present Treaty is in force shall constitute a basis for asserting, supporting or denying a claim to territorial sovereignty in Antarctica or create any rights of sovereignty in Antarctica. No new claim, or enlargement of an existing claim, to territorial sovereignty in Antarctica shall be asserted while the present Treaty is in force.

Prior to establishment of the Antarctic treaty, seven nations had territorial claims on parts of the continent. To establish the continent as a place for exclusive scientific cooperation, it was necessary to address questions of territorial claims. (See Figure 7.) The treaty, in Article IV, has adopted an interesting model of setting aside the issue of territorial claims by deferring them indefinitely, not renouncing, denying or supporting any claims. While this was done for the entire continent, in the case of Siachen a portion of the disputed area agreeable to both sides could be set aside for scientific research. This in no way takes away current claims but allows progress in diffusing tensions without first resolving the issue of territorial claims. 


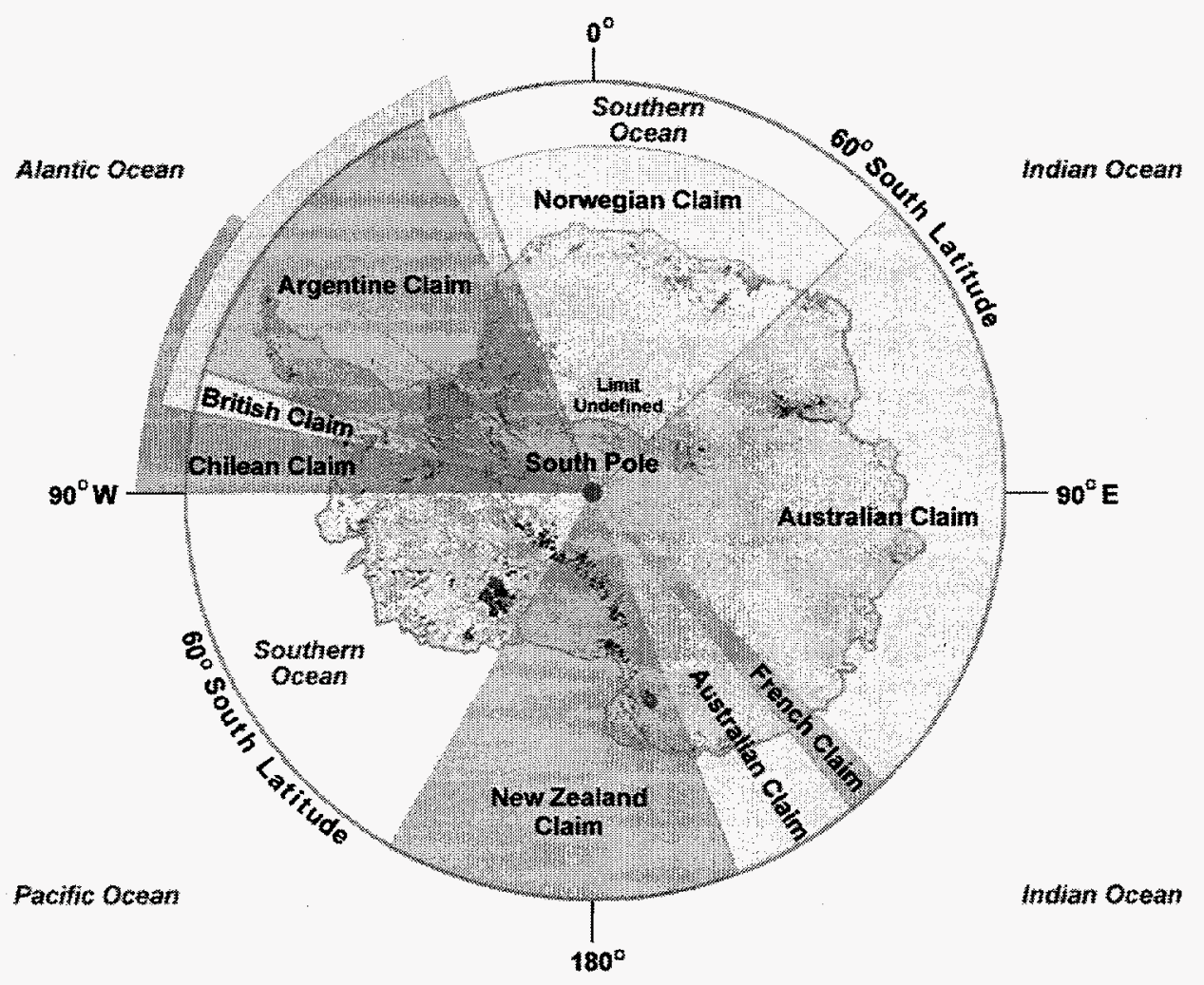

Figure 7. Antarctic Territorial Claims

The nature of territorial disputes is complex both legally and politically. The histories of the Siachen area and Antarctica are very different. Therefore, the specific legal and political precedent for addressing territorial claims in the Antarctic Treaty may not apply to the Siachen dispute. However, the concepts introduced in the Antarctic treaty might offer new insight into addressing the territorial concerns associated with the Siachen dispute.

\section{Article V}

1. Any nuclear explosions in Antarctica and the disposal there of radioactive waste material shall be prohibited.

2. In the event of the conclusion of international agreements concerning the use of nuclear energy, including nuclear explosions and the disposal of radioactive waste material, to which all of the Contracting Parties whose representatives are entitled to participate in the meetings provided for under Article $L X$ are parties the rules established under such agreements shall apply in Antarctica.

The nuclear issue is a sensitive one in South Asia because of concerns about nuclear proliferation. Therefore, attempts to tie nuclear issues to the Siachen dispute are likely to be counterproductive. However, if the parties did agree to prohibit nuclear testing and radioactive waste disposal in the limited area of Siachen, a positive step in nuclear cooperation between India and Pakistan could be achieved. The political willingness to 
agree to such provisions by India and Pakistan is feasible because neither of these activities is planned or appropriate in this high mountain region. In 1988 India and Pakistan formalized the Agreement of Prohibition of Attack on Nuclear Installations and Facilities. The Agreement was ratified in 1991 and lists of nuclear installations covered by the agreement were exchanged in 1992 .

\section{Article VI}

The provisions of the present Treaty shall apply to the area south of 60 deg South Latitude, including all ice shelves, but nothing in the present Treaty shall prejudice or in any way affect the rights, or the exercise of the rights, of any State under international law with regard to the high seas within that area.

An article such as this would be required to specify the exact area covered by the treaty. Clearly issues of laws of the seas do not apply in Siachen.

\section{Article VII}

1. In order to promote the objectives and ensure the observance of the provisions of the present Treaty, each Contracting Party whose representatives are entitled to participate in the meetings referred to in Article IX of the Treaty shall have the right to designate observers to carry out any inspection provided for by the present Article. Observers shall be nationals of the Contracting Parties which designate them. The names of observers shall be communicated to every other Contracting Party having the right to designate observers, and like notice shall be given of the termination of their appointment.

2. Each observer designated in accordance with the provisions of paragraph 1 of this Article shall have comple'e frecelom of access at any time to any or all areas of Antarctica.

3. All areas of Antarctica. including all stations, installations, and equipment within those areas, and all ships and aircraft at points of discharging or embarking cargoes or personnel in Anurctica. shall be open at all times to inspection by any observers designated in accordance with paragraph 1 of this article.

4. Aerial observation may he curried out at any time over any or all areas of Antarctica by any of the ('ontracting Parties having the right to designate observers.

5. Each Contracting Party shall, at the time when the present Treaty enters into force for it, inform the other Contracting Parties, and thereafter shall give them notice in advance, of

(a) all expeditions to and within Antarctica, on the part of its ships or nationals, and all expeditions to Antarctica organized in or proceeding from its territory;

(b) all stations in Antarctica occupied by its nationals; and

(c) any military personnel or equipment intended to be introduced by it into Antarctica subject to the conditions prescribed in paragraph 2 of Article I of the present Treaty. 
The ability to allow inspections of facilities on Siachen and to have provision for some aerial monitoring also help provide assurance that the activity on the glacier is limited to scientific research. Specific provisions would need to be developed on the nature and operations of inspections and overflights. Since the science center concept could be implemented bilaterally, as well as regionally or internationally, the details of inspections and overflights would be worked out in accordance with the parties who would be subject to the provisions of the agreement.

\section{Article VIII}

1. In order to facilitate the exercise of their functions under the present Treaty, and without prejudice to the respective positions of the Contracting Parties relating to jurisdiction over all other persons in Antarctica, observers designated under paragraph 1 of Article VII and scientific personnel exchanged under subparagraph 1 (b) of Article III of the Treaty, and members of the staffs accompanying any such persons, shall be subject only to the jurisdiction of the Contracting Party of which they are nationals in respect of all acts or omissions occurring while they are in Antarctica for the purpose of exercising their functions.

2. Without prejudice to the provisions of paragraph 1 of this Article, and pending the adoption of measures In pursuance of subparagraph 1 (e) of Article IX, the Contracting Parties concerned in any case of dispute with regard to the exercise of jurisdiction in Antarctica shall immediately consult together with a view to reaching a mutually acceptable solution.

Determining jurisdiction for all acts or omissions of the staff of a Siachen Science Center as well as mechanisms for addressing disputes will also be important in establishing this agreement among member states.

\section{Article IX}

1. Representatives of the Contracting Parties named in the preamble to the present Treaty shall meet at the City of Canberra within two months after the date of entry into force of the Treaty, and thereafter at suitable intervals and places, for the purpose of exchanging information, consulting together on matters of common interest pertaining to Antarctica, and formulating and considering, and recommending to their Governments, measures in furtherance of the principles and objectives of the Treaty, including measures regarding:

(a) use of Antarctica for peaceful purposes only;

(b) facilitation of scientific research in Antarctica;

(c) facilitation of international scientific cooperation in Antarctica;

(d) facilitation of the exercise of the rights of inspection provided for in Article VII of the Treaty;

(e) questions relating to the exercise of jurisdiction in Antarctica;

(f) preservation and conservation of living resources in Antarctica. 
2. Each Contracting Party which has become a party to the present Treaty by accession under Article XIII shall be entitled to appoint representatives to participate in the meetings referred to in paragraph 1 of the present Article, during such time as that Contracting Party demonstrates its interest in Antarctica by conducting substantial scientific research activity there, such as the establishment of a scientific station or the dispatch of a scientific expedition.

3. Reports from the observers referred to in Article VII of the present Treaty shall be transmitted to the representatives of the Contracting Parties participating in the meetings referred to in paragraph 1 of the present Article.

4. The measures referred to in paragraph I of this Article shall become effective when approved by all the Contracting Parties whose representatives were entitled to participate in the meetings held to consider those measures.

5. Any or all of the rights established in the present Treaty may be exercised as from the date of entry into force of the Treaty whether or not any measures facilitating the exercise of such rights have been proposed, considered or approved as provided in this Article.

The need to set up an organization to administer control of the Siachen Science Center is reflected in this article. This organization, which would include representatives of signatory countries, could decide policy; select research experiments; collect, share and publish information jointly; and address other issues associated with funding and operating the center.

\section{Article $X$}

Each of the Contracting Parties undertakes to exert appropriate efforts consistent with the Charter of the United Nations, to the end that no one engages in any activity in Antarctica contrary to the principles or purposes of the present Treaty.

This article reinforces the underlying intent that all efforts be made to meet the spirit as well as letter of the treaty.

\section{Article XI}

1. If any dispute arises between two or more of the Contracting Parties concerning the interpretation or application of the present Treaty, those Contracting Parties shall consult among themselves with a view to having the dispute resolved by negotiation, inquiry, mediation, conciliation, arbitration, judicial settlement or other peaceful means of their own choice.

2. Any dispute of this character not so resolved shall, with the consent, in each case, of all parties to the dispute, be referred to the International Court of Justice for settlement; but failure to reach agreement or reference to the International Court shall not absolve parties to the dispute from the responsibility of continuing to seek to resolve it by any of the various peaceful means referred to in paragraph 1 of this Article. 
This article provides for peaceful and appropriate legal resolution of disputes arising from the agreement. It further commits the signatories to continue seeking peaceful resolution of all disputes. Provisions such as these would build confidence that a Siachen resolution was intended to keep the peace despite disagreements that might arise.

\section{Article XII}

1. (a) The present Treaty may be modified or amended at any time by unanimous agreement of the Contracting Parties whose representatives are entitled to participate in the meeting provided for under Article LX. Any such modification or amendment shall enter into force when the depositary Government has received notice from all such contracting Parties that they have ratified it.

(b) Such modification or amendment shall thereafter enter into force as to any other Contracting Policy when notice of ratification by it has been received by the depositary Government. Any such Contracting Party from which no notice of ratification is received within a period of two years from the date of entry into force of the modification or amendment in accordance with the provisions of subparagraph 1 (a) of this Article shall be deemed to have withdrawn from the present Treaty on the date of the expiration of such period.

2. (a) If after the expiration of thirty years from the date of entry into force of the present Treaty, any of the Contracting Parties whose representatives are entitled to participate in the meetings provided for under Article LX so requests by a communication addressed to the depositary Government, a Conference of all the Contracting Parties shall be held as soon as practicable to review the operation of the Treaty.

(b) Any modification or amendment to the present Treaty which is approved at such a Conference by a majority of the Contracting Parties there represented, including a majority of those whose representatives are entitled to participate in the meetings provided for under Article $L X$, shall be communicated by the depositary Government to all the Contracting Parties immediately after the termination of the Conference and shall enter into force in accordance with the provisions of paragraph 1 of the present Article.

(c) If any such modification or amendment has not entered into force in accordance with the provisions of subparagraph 1 (a) of this Article within a period of two years after the date of its communication to all the Contracting Parties, any Contracting Party may at any time after the expiration of that period give notice to the depositary Government of its withdrawal from the present Treaty, and such withdrawal shall take effect two years after the receipt of the notice by the depositary Government.

As with all treaties, this article specifies the conditions for amendment, withdrawal, and duration of the treaty. The specific requirements for these provisions would need to be established during negotiation of a Siachen agreement. 


\section{Article XIII}

1. The present Treaty shall be subject to ratification by the signatory States. It shall be open for accession by any State which is a Member of the United Nations, or by any other State which may be invited to accede to the Treaty with the consent of all the Contracting Parties whose representatives are entitled to participate in the meetings provided for under Article $L X$ of the Treaty.

2. Ratification of or accession to the present Treaty shall be effected by each State in accordance with its constitutional processes.

3. Instruments of ratification and instruments of accession shall be deposited with the Government of the United States of America, hereby designated as the depositary Government.

4. The depositary Government shall inform all signatory and acceding States of the date of each deposit of an instrument of ratification or accession, and the date of entry into force of the Treaty and of any modification or amendment thereto.

5. Upon the deposit of instruments of ratification by all the signatory States, the present Treaty shall enter into force for these States and for States which have deposited instruments of accession. Thereafter the Treaty shall enter into force for any acceding State upon the deposit of its instruments of accession.

6. The present Treaty shall be registered by the depositary Government pursuant to Article 102 of the Charter of the United Nations.

This article addresses the process of treaty ratification.

\section{Article XIV}

The present Treaty, done in the English, French, Russian and Spanish languages, each version being equally authentic, shall be deposited in the archives of the Government of the United States of America, which shall transmit duly certified copies thereof to the Governments of the signatory and acceding States.

In Witness Whereof, the undersigned Plenipotentiaries, duly authorized, have signed the present Treaty.

Done at Washington this first day of December, one thousand nine hundred and fiftynine.

Finally, the treaty languages and deposit location for signatory and acceding States are specified as they would need to be in a formal Siachen agreement. 


\section{References}

1. Samina Ahmed and Varun Sahni, "Freezing the Fighting: Military Disengagement on the Siachen Glacier," CMC Occasional Paper, Sandia National Laboratories, SAND98-0505/1, Albuquerque, New Mexico, March 1998.

2. Arms Control and Disarmament Agreements: Texts and Histories of the Negotiations, United States Arms Control and Disarmament Agency, Washington, D.C., 1990.

3. Robert G. Wirsing, Pakistan's Security Under Zia, 1977-1988: The Policy Imperatives of a Peripheral Asian State, St. Martin's Press, New York, 1991.

4. G. Noorani, Easing the Indo-Pakistani Dialogue on Kashmir: Confidence-Building Measures for the Siachen Glacier, Sir Creek and the Wular Barrage Disputes, Occasional Paper 16, The Henry L. Stimson Center, Washington, D. C., 1994.

5. Lt. Gen. M. L. Chibber, "Siachen-The Untold Story," Indian Defense Review, January 1990.

6. P. S. Sidhu, "Siachen: The Forgotten War," India Today, May 31, 1992, pp. 86-101.

7. Edward W. Desmond, "War at the Top of the World," Time Magazine, July 31, 1989.

8. Martin A. Sugarman, War Above the Clouds: Siachen Glacier, Sugarman Productions, Malibu, California, 1996.

9. Rakesh Sood, "Implementing Confidence Building Measures-India and Her Neighbors," paper presented at the Ninth Regional Disarmament Meeting in the AsiaPacific Region, Katmandu, Feb. 24-26, 1997. 


\section{Distribution}

350. MS 1373 CMC Library, 5341

1 MS 9018 Central Tech Files, 8940-2

2 MS 0899 Technical Library, 4916

2 MS 0619 Review \& Approval Desk, 12690 for DOE/OSTI 